https://doi.org/10.48009/1_iis_2006_357-361

\title{
SERVICE QUALITY EXPECTATIONS AND PERCEPTIONS: USE OF THE SERVQUAL INSTRUMENT FOR REQUIREMENTS ANALYSIS
}

\author{
Craig K. Tyran, Western Washington University, craig.tyran@wwu.edu \\ Steven C. Ross, Western Washington University, steve.ross@wwu.edu
}

\begin{abstract}
The MIS Faculty at a public university employed an instrument that measures service quality - often used in marketing research - to assist in the specification of requirements for a proposed academic advising support system (AASS). Results from the survey of 110 students identified needs that an AASS could meet. This paper describes the systems requirements portion of the project.
\end{abstract}

Keywords: Academic Advising, Service Quality, SERVQUAL, Support Systems

\section{INTRODUCTION}

Academic advising refers to the practice of assisting students as they determine a program of study that will meet their intellectual and career interests and will satisfy university and academic major graduation requirements. For a university, the quality of academic advising services can have important implications for students, including student retention and graduation rates [5]. Given the importance of academic advising in higher education, the topic has been the subject of much research. Useful general references on academic advising include Gordon [6] and publications by the National Academic Advising Association (e.g., [11]). A review of the literature on academic advising suggests that there are several organizational models for advising [10]. The most common advising model is the "faculty" model in which faculty members deliver advising services to students. While there are benefits to this approach, such as the development of student/faculty relationships and low cost to the institution, there can also be problems related to low faculty commitment and inconsistent advising quality [10].

One approach to address such problems may be to use information technology to support advising services. Bellenger and Bellenger [1] discuss the benefits that would accrue from an automated system - time efficiency, cost reduction, and accuracy. They also suggest that such a system would solve several problems, including information disappearance, information delay, and information distortion.
Several more-recent articles [3, 7] also discuss the potential benefits of technology-based solutions.

Within the College of Business at Western Washington University (WWU), we have adopted a "faculty" model for the delivery of academic advising. Similar to other universities that have used this model, we have encountered difficulties with respect to the quality and availability of academic advising services. In an effort to address the problems, the Department of Decision Sciences (DSCI) at WWU has begun to investigate the feasibility of an automated system - an Academic Advising Support System (AASS). The purpose of this manuscript is to discuss the process that we used to adapt and implement a well-known service quality survey instrument to help determine the system requirements for the system. The method that we followed provided a useful framework for approaching the requirements specification from the perspective of service quality and helped us to identify key priorities for the proposed system.

\section{Advising at WWU}

WWU is a regional public university located in the Western United States. Within the College of Business at WWU, the DSCI Department offers a degree in Business Administration, with concentrations in MIS, Operations Management, and Manufacturing Management. The College of Business at WWU does not have a centralized advising function. Students applying for admission are informed by the college office whether or not they meet the minimum qualifications. Beyond that, all advising is handled by the department housing the student's major. Each DSCI student is assigned to an advisor - a faculty member with whom the student is expected, but not required, to meet. The advising expectations of DSCI faculty are to address general curriculum questions and help the students develop a course schedule that will address each student's academic interests and lead to timely graduation. Currently, all students in the DSCI Department at WWU are expected to fill out a "plan of study" form listing all required business courses as well as their choice of elective courses (together, these comprise about $50 \%$ of the total hours needed for graduation). 
This form is supposed to be reviewed in a meeting between the student and his or her advisor shortly after the student is accepted into the program (normally, the first academic quarter of junior year). However, there is little effort made to enforce this requirement. A review of documents on file in the department office indicates that fewer than $50 \%$ of the students complete this form on a timely basis. Many students delay the task until they apply for graduation.

Based on anecdotal feedback from students, we had the general sense that advising services could be improved. For example, each year we learn about students who have encountered problems near graduation due to poor class schedule planning (e.g., failure to plan for a prerequisite course). As noted above, many of the students fail to complete the "plan of study" document on a timely basis. In some cases, "advising" problems appear to be attributed to a student failing to meet with an advisor for plan review (and thereby making poor decisions regarding scheduling). In other cases, the problem was due to an advisor error. Also, we have heard occasional grumbling from students about problems regarding the responsiveness or attentiveness of a faculty advisor.

Given the concerns with the existing advising approach, the Chair of the DSCI department suggested that a computerized support system might help address the perceived problems with advising services. Two faculty members in the department undertook a project to formally assess the quality of advising services and establish the requirements for the proposed advising support system project. In the following sections of the manuscript, we describe the method used to assess the quality of advising services and to help determine the requirements and priorities for the proposed system. As part of this process, we modified the SERVQUAL instrument [12] for advising services. The modified instrument included three dimensions and was found to have high scale reliability, as well as convergent and discriminant validity. We conclude with a discussion of how the findings from the requirements determination stage will be used to guide the development of a Webbased support system for advising.

\section{STRATEGY FOR REQUIREMENTS ANALYSIS}

The development or acquisition of a new computerized system to support academic advising was expected to represent a significant investment of resources for the DSCI department. Before making a decision on whether or not to build or acquire an advising support system, we conducted a system requirements analysis to better understand the concerns and needs of our potential system users (i.e., the students). To help with this stage of the project, we realized that it would be important for us to adopt a customer service orientation. As mentioned in an article by Spicuzza [14], advising in higher education is characteristic of the service industries. He noted that "there is a plethora of studies that identify student dissatisfaction with the advising process and with advisors who are uninterested and not approachable" [14: 49]. Among the components of the service model that he suggests be adopted for academic advising are an understanding of customer needs and provision of resources. A four-year study at his institution found that a unit that took a service approach to advising had higher retention rates than the remainder of the university.

As noted by Hoffer, George, \& Valacich [9], survey questionnaires can be a particularly efficient way to gather information for system requirements. To obtain a more inclusive understanding of how the students assessed our advising services, we conducted a survey of all students assigned to the department. We examined the service quality literature to identify a survey instrument to help us assess the quality of our advising services and the priorities (if any) for system support. We used the well-known SERVQUAL instrument [12]. The SERVQUAL questionnaire includes scales for five different aspects of service quality: information resources, reliability, responsiveness, assurance, and empathy. The survey includes two sets of 22-item measures. One set of measures is used to assess expectations regarding service quality, while the second set is used to determine perceptions regarding actual service quality. Researchers have examined the application of the SERVQUAL instrument for many different types of service organizations ranging from retail organizations to universities $[2,4]$. While there has been considerable discussion in the literature regarding the stability of the factor structure of the SERVQUAL instrument and its use of "gap scores" to assess service quality, it is generally concluded that SERVQUAL can serve as a useful basis for service quality assessment [2].

Modifications to the SERVQUAL instrument presented by Parasuraman, et al. [12] were made prior to the implementation of our survey. As suggested by Parasuraman, Zeithaml, \& Berry [13], it can be appropriate to modify the items of the SERVQUAL instrument to make the survey more relevant to the context of a particular service 
environment. Also, it can be appropriate to add or drop items [2]. In the case of our study, the four items associated with the "Tangibles" factor in the 1991 SERVQUAL instrument (e.g., "XYZ has modernlooking equipment") did not appear to be particularly relevant for the context of academic advising service quality. Hence, these items were not included with our survey. We also dropped the item "E20" from the 1991 SERVQUAL instrument, as this item appeared to be very similar to item "E18." In addition to dropping survey items, new items were added to the instrument. Engelland, et al. [4] found that the provision of information resources can be an important aspect of service quality for the academic environment. Drawing on this work, we added four new items to our version of the SERVQUAL instrument to capture an "Information Resources" factor. (The new items are listed as the first four items in Table 1.) Lastly, the wordings of the remaining 1991 SERVQUAL items were modified slightly to fit the academic advising context.

Table 1. Factor Loadings and Scale Reliability for Academic Advising Services SERVQUAL Instrument

\begin{tabular}{|l|c|c|c|}
\hline & \multicolumn{2}{|c|}{ Factor Loadings and Scale Reliability } \\
\hline $\begin{array}{l}\text { Original SERVQUAL Factor Dimension (from } \\
\text { [12]) - Illustrative Portion of Survey Item }\end{array}$ & $\begin{array}{c}\text { Information } \\
\text { Resources }\end{array}$ & $\begin{array}{c}\text { Reliability and } \\
\text { Responsiveness }\end{array}$ & $\begin{array}{c}\text { Knowledge and } \\
\text { Empathy }\end{array}$ \\
\hline $\begin{array}{l}\text { New Item - Will have advising-related information } \\
\text { readily available for students. }\end{array}$ & .68 & & \\
\hline $\begin{array}{l}\text { New Item - Information regarding graduation } \\
\text { requirements will be available. }\end{array}$ & .46 & & \\
\hline $\begin{array}{l}\text { New Item - Will provide a full range of resources to } \\
\text { support advising. }\end{array}$ & .69 & & \\
\hline $\begin{array}{l}\text { New Item - Complete information regarding } \\
\text { courses will be available }\end{array}$ & .43 & -.61 & \\
\hline $\begin{array}{l}\text { Reliability - When someone promises to do } \\
\text { something by a certain time, then they will do so. }\end{array}$ & & -.53 & \\
\hline $\begin{array}{l}\text { Reliability - Will show a sincere interest in solving } \\
\text { the problem. }\end{array}$ & & -.54 & \\
\hline $\begin{array}{l}\text { Reliability - Will provide services right the first } \\
\text { time. }\end{array}$ & & -.93 & \\
\hline $\begin{array}{l}\text { Reliability - Will provide services at the time they } \\
\text { promise to do so. }\end{array}$ & & -.43 & \\
\hline Reliability - Will insist on error-free records. & & -.56 & \\
\hline $\begin{array}{l}\text { Responsiveness - Will tell exactly when advising } \\
\text { services will be performed. }\end{array}$ & & -.74 & \\
\hline $\begin{array}{l}\text { Responsiveness - Will give prompt service to } \\
\text { students. }\end{array}$ & & & \\
\hline $\begin{array}{l}\text { Assurance - Will have the knowledge to answer } \\
\text { questions. }\end{array}$ & & & \\
\hline $\begin{array}{l}\text { Empathy - Will have operating hours convenient } \\
\text { for students. }\end{array}$ & & & .82 \\
\hline $\begin{array}{l}\text { Empathy - Will have the students' best interests at } \\
\text { heart. }\end{array}$ & & & \\
\hline $\begin{array}{l}\text { Empathy - Will understand the needs of the } \\
\text { students. }\end{array}$ & & & \\
\hline Scale Reliability (Cronbach's alpha) & & \\
\hline
\end{tabular}

Notes: 1. The first column in the table above provides a portion of each survey question. The survey questions used for the study followed the format used by Parasuraman, et al. [13]. To assess expectations regarding service quality, the survey questions used a form such as "Excellent advising groups will have advising-related information readily available for students." To assess perceptions regarding actual service quality, the survey questions used a form such as "The advising group in my major/concentration has advising-related information readily available for students." 
2. The factor analysis was conducted using the SERVQUAL difference scores. Scale reliability is for the difference scores.

3. The factor analysis used Principle Axis Factoring and oblique rotation (Oblimin).

4. The four items listed at the top of the table were new items developed for this study to create a new "Information Resources" scale.

5. Only factor loadings over .40 are shown.

6. $\mathrm{N}=110$

In addition to the adapted version of the SERVQUAL instrument, our survey also included a question designed to determine the relative importance of service quality dimensions, and an open-ended question in which students provided comments concerning academic advising services within the DSCI department.

\section{SURVEY METHODOLOGY}

\section{Sample}

The survey sample included all students who had declared an academic concentration in the Department of Decision Sciences. A total of 142 students were surveyed, resulting in 110 usable surveys. The respondents represented three areas of academic concentration: Information Systems (67\% of respondents), Manufacturing and Supply Chain Management (18\%), and Operations Management $(15 \%)$. Eighty-four percent of the respondents were male. Most respondents indicated knowledge of their concentration area and advisor, as $98 \%$ of the students reported that they had knowledge of the required courses for their concentration, $77 \%$ had knowledge of the elective courses, and $81 \%$ knew the name of their faculty advisor.

\section{Factor Analysis}

We used the iterative data reduction approach described by Parasuraman, et al. [12, 13] for our analysis. Specifically, the difference scores for each item (i.e., expected minus perceived service quality) were factor analyzed using the principal axis factoring procedure followed by an oblique rotation. As the dimensionality of SERVQUAL has been found to vary across service domains and organizations [12], we did not constrain the factor analysis to a pre-defined number of factors. Similar to the approach used by Carmen [2], in our first iteration we retained all factors with eigenvalues greater than one. Initially, six factors were present. However, some items had relatively low factor loadings. Following the guidelines of Hair, Anderson, Tatham, and Black [8], items with factor loadings of 0.4 or lower were not considered to be significant.
These items, along with an item which loaded on only one factor were dropped, resulting in fifteen items. The remaining items were factored again, resulting in three factors which explained 55\% of the variance (see Table 1). As indicated in Table 1, based on the factor structure, the convergent and discriminant validity of the three factors is good. Also, the reliability of the three resulting scales is strong with Cronbach alpha statistics ranging from $0.75-0.88$.

A review of the top rows of Table 1 shows that the new "Information Resources" items created for this study all loaded into one factor. The other items for SERVQUAL instrument loaded onto two factors: one factor included all five of the original SERVQUAL reliability items plus two of the four SERVQUAL responsiveness items, while the other factor included 3 of the 4 original SERVQUAL empathy items, plus one assurance item. As noted by Carmen [2], it is not unusual for the SERVQUAL factor dimensions to vary across organizational settings. For our study, we have labeled the three factors in Table 1 as "Information Resources," "Reliability/ Responsiveness," and "Knowledge/Empathy" (the one assurance item included in the third factor concerns the issue of knowledge).

\section{SURVEY RESULTS}

The assessment of academic services was performed using the adapted SERVQUAL instrument. The scale reliability for each of the three SERVQUAL scales was good, with values for Cronbach's alpha for the three dimensions ranging from 0.74 to 0.89 . The students' expectations for advising service quality was generally high, with ratings as follows: 5.99 (on a 7 point scale) for "Information Resources," 5.88 for "Reliability/ Responsiveness," and 6.17 for "Knowledge/ Empathy. The actual ratings for service quality were: 5.46 for "Information Resources," 5.30 for "Reliability/Responsiveness," and 5.36 for "Knowledge/Empathy." The service level gap scores (i.e., the mean "expected" service quality score minus the mean "actual" score for each service dimension) indicated that actual advising services fell short of the students' expectations (the gap scores ranged from 
.53 to .81 ), with the largest gap score corresponding to the service dimension of "Knowledge/Empathy." The difference between the mean expected and mean actual service quality was assessed for each of the service quality dimensions using paired sample $\mathrm{T}$ Tests. For each dimension, the actual service quality was found to be significantly below the expected service quality $(\mathrm{p}<0.01)$. Based on these findings, it appears that advising service quality in all three areas could be improved, with the most improvement needed in the "Knowledge/Empathy" dimension.

While the gap scores provide a measure of how well advising services were meeting the expectations of students, these scores do not necessarily indicate the service areas of highest priority for the students. Following the approach proposed by Parasuraman, et al. [12], the relative importance of the five original SERVQUAL dimensions was assessed by asking students to allocate 100 points across the dimensions, with the number of points allocated to each dimension corresponding to relative importance. If students considered all dimensions to be equal, then each dimension would have a mean value of 20 points. Based on our survey, it was clear that the students considered some dimensions to be more important than others. The dimension of information resources was considered to be the most important with a mean value of 24.9 points. The second ranked area of priority was reliability (mean of 21.2 points). Each of the other three dimensions had a mean score below 20 points: responsiveness (18.9 points), assurance (18.1 points), and empathy (16.9 points). For the students in our study, it was interesting to find that the service area with the largest shortfall between performance and expectations (i.e., "Knowledge/Empathy") corresponded to the areas considered to be least important to service quality. From the perspective of the students, it appears that the service level gap related to the "Knowledge/Empathy" dimension may represent a lower priority issue for system support than the other two dimensions shown in Table 1.

Comments were made on 39 of the surveys. These support the numerical findings. One theme difficulty in scheduling a meeting with the advisor was found in almost $80 \%$ of the comments. Incorrect advice was noted in $10 \%$ of the comments, while positive experiences and accurate advice were reported in the final $10 \%$. Embedded in several of the comments was a suggestion that more on-line resources be made available.

\section{Taking the Next Step}

The survey process described above helped the system developers to better understand the requirements for an academic advising system. In particular, the survey provided an efficient means to identify and evaluate different aspects of service quality that were relevant for advising services. Based on the findings from the survey, it was concluded that an automated system (i.e., the proposed AASS) would have the potential to effectively supplement the existing, traditional form of advising services. The proposed system could address the salient service quality issues by providing comprehensive, reliable advising information on a "24/7" basis. Such a system could reduce student frustration with the reported shortcomings of the traditional advising approach and could facilitate a student's progress toward degree completion. Hence, the DSCI faculty made the decision to proceed with systems development of the advising support system.

\section{CONCLUSIONS}

This study used a well-known survey instrument SERVQUAL - adapted to a specific situation. There are implications for both systems development as well as assessment of academic advising. With regard to systems development, we found that SERVQUAL may be used to identify key focal areas for a serviceoriented information system. As the project progresses, we plan to use a similar instrument (revised to reflect the nature of electronic systems) for user acceptance testing and system monitoring to ensure that the system continues to meet the needs of the user base. Also, we found that this study yielded a strong set of scales appropriate for assessment of advising services. While more research is required to assess the adaptability of the SERVQUAL instrument to other advising environments (e.g., different schools use different models of advising), the instrument we used did exhibit strong validity for our data pool. In particular, the new "Information Resources" scale created for this project appears to be a useful way to assess this important dimension of academic advising services quality.

\section{REFERENCES}

1. Bellenger, J.E. \& Bellenger, D.N. (1987). Guidelines for computerizing your information system for academic program counseling: dealing with people problems, NASPA Journal, 24(4), 53-60.

2. Carmen, J.M. (1990). Consumer perceptions of service quality: An assessment of the 
SERVQUAL dimensions, Journal of Retailing, 66(1), 33-55.

3. Comer, J., Nute, T., \& Rodjak, D. (1991). CASAS: Engineering Software Applications, Information and Software Technology, 33(6), 443-450.

4. Engelland, B.T., Workman, L., \& Singh, M. (2000). Ensuring service quality for campus career services centers: A modified SERVQUAL scale, Journal of Marketing Education, 22(3), 236-245.

5. Glennen, R.E. (1996). How advising and retention of students improves fiscal stability, NACADA Journal, 16, 38-46.

6. Gordon, V.N. (1994) Academic Advising: An Annotated Bibliography. Westport, CT: Greenwood Press.

7. Grupe, F.H. (2002). An Internet-based expert system for selecting an academic major, The Internet and Higher Education, 5, 333-344.

8. Hair, J.F., Anderson, R.E., Tatham, R.L., \& Black, W.C. (1998). Multivariate Data Analysis ( $5^{\text {th }}$ Edition). Upper Saddle River, NJ: Prentice Hall.

9. Hoffer, J.A., George, J.F., \& Valacich, J.S. Modern Systems Analysis and Design $\left(3^{\text {rd }}\right.$ Edition). Upper Saddle River, NJ: Prentice Hall.
10. King, M.C. \& Kerr, T.J. (1995). Organizing and Delivering Academic Advising for First-Year Students, in First-Year Academic Advising: Patterns in the Present, Pathways to the Future (NACADA monograph, M.L. Upcraft \& G.L. Kramer, editors), 35-43.

11. NACADA Journal (2003). Technology and Advising: Annotated Bibliography for research published prior to 1999, https://www.nacada.ksu.edu/Clearinghouse/Rese arch_Related/advtechbib.htm read March 9, 2006.

12. Parasuraman, A., Berry, L.L., \& Zeithaml, V.A. (1991). Refinement and Reassessment of the SERVQUAL Scale, Journal of Retailing, 67(4), 420-450.

13. Parasuraman, A., Zeithaml, V.A. \& Berry, L.L. (1988). SERVQUAL: A multiple-item scale for measuring customer perceptions of service quality, Journal of Retailing, 64(1), 12-40.

14. Spicuzza, F.J. (1992). A customer service approach to advising: Theory and application, NACADA Journal, 12, 49-58. 